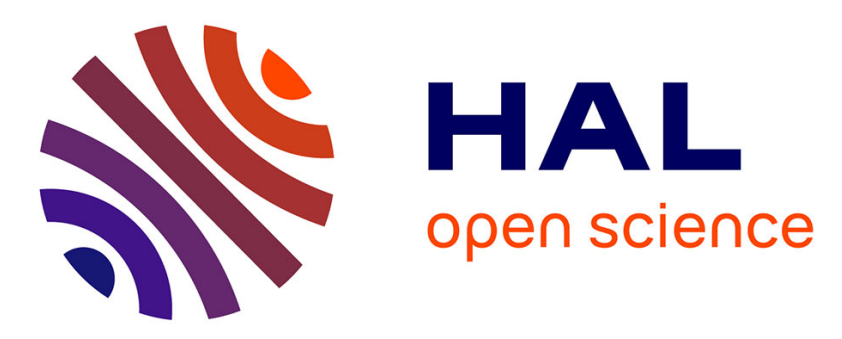

\title{
Functional changes of AMPA responses in human induced pluripotent stem cell-derived neural progenitors in fragile $\mathrm{X}$ syndrome
}

\author{
Venkat Swaroop Achuta, Tommi Möykkynen, Ulla-Kaisa Peteri, Giorgio \\ Turconi, Claudio Rivera, Kari Keinänen, Maija L Castrén
}

\section{To cite this version:}

Venkat Swaroop Achuta, Tommi Möykkynen, Ulla-Kaisa Peteri, Giorgio Turconi, Claudio Rivera, et al. Functional changes of AMPA responses in human induced pluripotent stem cell-derived neural progenitors in fragile X syndrome. Science Signaling, 2018, 11 (513), pp.eaan8784. 10.1126/scisignal.aan8784 . hal-01961931

\section{HAL Id: hal-01961931 \\ https://hal.science/hal-01961931}

Submitted on 20 Dec 2018

HAL is a multi-disciplinary open access archive for the deposit and dissemination of scientific research documents, whether they are published or not. The documents may come from teaching and research institutions in France or abroad, or from public or private research centers.
L'archive ouverte pluridisciplinaire HAL, est destinée au dépôt et à la diffusion de documents scientifiques de niveau recherche, publiés ou non, émanant des établissements d'enseignement et de recherche français ou étrangers, des laboratoires publics ou privés. 


\section{Functional changes of AMPA responses in human induced pluripotent stem cell-derived neural progenitors in fragile $X$ syndrome}

\author{
Venkat Swaroop Achuta, ${ }^{1}$ Tommi Möykkynen, ${ }^{2}$ Ulla-Kaisa Peteri, ${ }^{1}$ Giorgio Turconi, ${ }^{1}$ \\ Claudio Rivera, ${ }^{3,4,5}$ Kari Keinänen, ${ }^{2}$ Maija L. Castrén ${ }^{1,6,7 *}$
}

\begin{abstract}
Altered neuronal network formation and function involving dysregulated excitatory and inhibitory circuits are associated with fragile X syndrome (FXS). We examined functional maturation of the excitatory transmission system in FXS by investigating the response of FXS patient-derived neural progenitor cells to the glutamate analog (AMPA). Neural progenitors derived from induced pluripotent stem cell (iPSC) lines generated from boys with FXS had augmented intracellular $\mathrm{Ca}^{2+}$ responses to AMPA and kainate that were mediated by $\mathrm{Ca}^{2+}$-permeable AMPA receptors (CP-AMPARs) lacking the GluA2 subunit. Together with the enhanced differentiation of glutamateresponsive cells, the proportion of CP-AMPAR and $N$-methyl-D-aspartate (NMDA) receptor-coexpressing cells was increased in human FXS progenitors. Differentiation of cells lacking GluA2 was also increased and paralleled the increased inward rectification in neural progenitors derived from Fmr1-knockout mice (the FXS mouse model). Human FXS progenitors had increased the expression of the precursor and mature forms of miR-181a, a microRNA that represses translation of the transcript encoding GluA2. Blocking GluA2-lacking, CP-AMPARs reduced the neurite length of human iPSC-derived control progenitors and further reduced the shortened length of neurites in human FXS progenitors, supporting the contribution of CP-AMPARs to the regulation of progenitor differentiation. Furthermore, we observed reduced expression of Gria2 (the GluA2-encoding gene) in the frontal lobe of FXS mice, consistent with functional changes of AMPARs in FXS. Increased $\mathrm{Ca}^{2+}$ influx through CP-AMPARs may increase the vulnerability and affect the differentiation and migration of distinct cell populations, which may interfere with normal circuit formation in FXS.
\end{abstract}

\section{INTRODUCTION}

Abnormalities in glutamate receptor-mediated plasticity and a dysregulated balance of excitation and inhibition in cortical networks are implicated in fragile X syndrome (FXS) (1-6). FXS is the most common single-gene cause of inherited intellectual disability (7). The cognitive impairment varies from mild to severe, and the comorbid neurobehavioral features generate high variation of the FXS phenotype. FXS is caused by a triplet CGG repeat expansion with more than 200 repeats in the fragile $X$ mental retardation 1 (FMR1) gene (8). The mutation results in promoter hypermethylation, leading to transcriptional silencing of the gene and the absence of FMR1 protein (FMRP) (9). FMRP is an RNA binding protein that regulates translation of many mRNAs essential for brain function $(10,11)$. The expression of FMRP increases during neuronal differentiation, and its absence results in abnormal fate determination and differentiation of neural progenitors (12-19). Previous studies have shown that human induced pluripotent stem cell (iPSC)-derived neural progenitors retain the FMR1 gene methylation (15) and differentially express a number of genes during neuronal differentiation compared with normal controls (20-22). Human FXS iPSC-derived neuronal cells and cortical progenitors derived from Fmr1-knockout (Fmr1-KO) mice show altered neurite growth $(12,15,17,20,23)$, which reflects dysregulation of genes involved in

\footnotetext{
1Department of Physiology, Faculty of Medicine, University of Helsinki, P.O. Box 63 FIN-00014 Helsinki, Finland. ${ }^{2}$ Division of Biochemistry and Biotechnology, Department of Biosciences, University of Helsinki, P.O. Box 56, FIN-00014, Helsinki, Finland. ${ }^{3}$ Neuroscience Center, University of Helsinki, P.O. Box 56, FIN-00014 Helsinki, Finland. ${ }^{4}$ Institut de Neurobiologie de la Méditerranée, INSERM, Unité 901, 13009 Marseille, France. ${ }^{5}$ Aix-Marseille Université, Unité Mixte de Recherche 901, 13273 Marseille, France. ${ }^{6}$ Rinnekoti Foundation, Rinnekodintie 10, FIN-02980 Espoo, Finland. ${ }^{7}$ Autism Foundation, Kuortaneenkatu 7B, FIN-00520 Helsinki, Finland.

${ }^{*}$ Corresponding author. Email: maija.castren@helsinki.fi
}

neurite growth and axon guidance (20-22). There is evidence that abnormal calcium signaling through glutamate receptors contributes to the aberrant differentiation of FXS progenitors (23). Pluripotent stem cell-derived FXS neurons display defects in their action potential properties (18), but functional alterations of distinctive neuronal populations derived from FXS iPSCs have not been explored in detail. Increased glutamate responses via type I metabotropic glutamate receptors (mGluRs) in FXS neural progenitors (23) contribute to disordered neurogenesis that underlies impaired learning of Fmr1-KO mice (24), whereas increased AMPA receptor (AMPAR) internalization is implicated as the prime cellular mechanism for cognitive deficits in FXS (25-28). Studies with Fmr1-KO mice show dysregulated maturation of glutamatergic signaling that delays the synaptic plasticity period in the somatosensory cortex of these mice (1). Exaggerated type I mGluR activation, which couples to increased protein synthesis and abnormal calcium signaling, appears to be a key player in the neuronal plasticity defects in the absence of $\operatorname{FMRP}(2,28,29)$.

Glutamate receptor-mediated responses via metabotropic and ligand-gated ionotropic receptors are important regulatory signals in neuronal differentiation (30-32). Activation of ionotropic AMPARs increases intracellular $\mathrm{Ca}^{2+}$ concentration $\left(\left[\mathrm{Ca}^{2+}\right]_{\mathrm{i}}\right)$ either directly through $\mathrm{a} \mathrm{Ca}^{2+}$-permeable AMPARs (CP-AMPARs) or indirectly through depolarization and activation of voltage-gated channels $(31,32)$. AMPARs are tetrameric assemblies consisting of subunits GluA1 to GluA4 $(33,34)$. Only AMPARs that lack the Q/R site RNA-edited GluA2 subunit are calcium-permeable; they show strong inward rectification caused by intracellular polyamine block $(35,36)$. Given the diverse effects of $\mathrm{Ca}^{2+}$ signaling, tight regulation of CP-AMPAR abundance participates in cell type, developmental stage, and brain region-dependent control of calcium homeostasis in the central nervous system (37-40). 
A

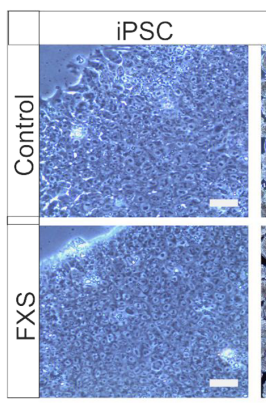

B

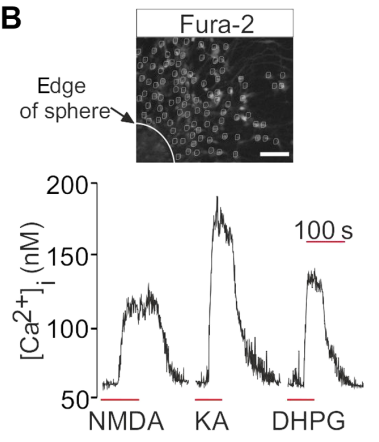

E

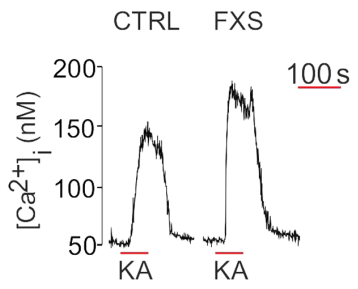

Neurospheres
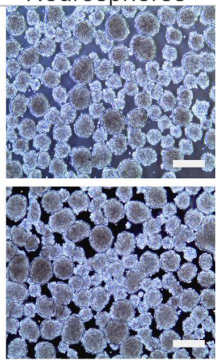

C

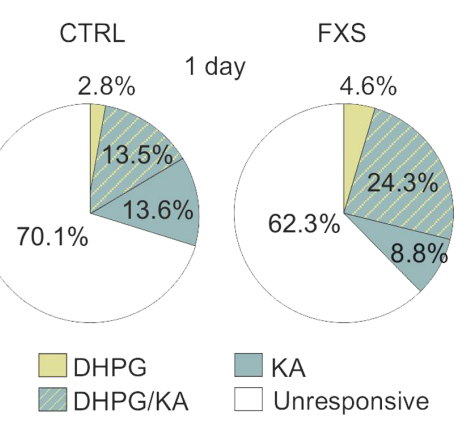

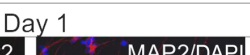
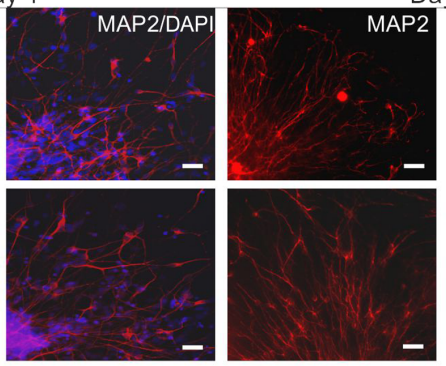

D

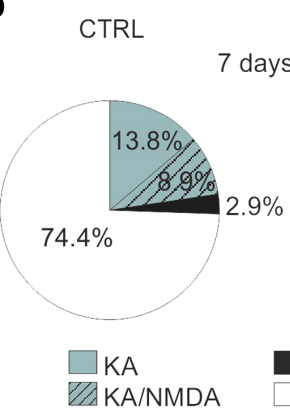

FXS
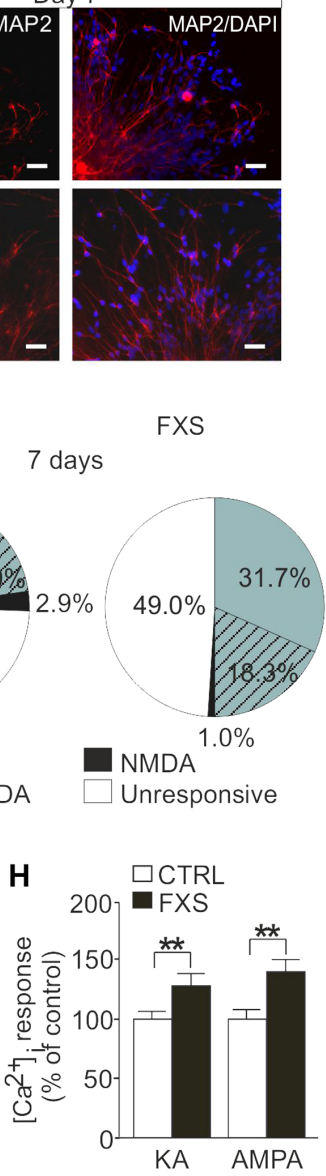

Fig. 1. Increased differentiation of cells expressing AMPARs in human FXS neural progenitors. (A) Representative images of iPSCs, neurospheres, and neurospheres immunostained for MAP2 (red) at days 1 and 7 of differentiation. DAPI, 4',6-diamidino-2-phenylindole. (B) Fluorescence image of a neurosphere and representative cell responses to NMDA, KA, and DHPG after stimulation as indicated. (C and D) Pie charts showing the proportions of cells responsive to DHPG and KA at day 1 and to KA and NMDA at day 7 of differentiation (responsive cells/total cell number). $n=239$ cells (CTRL) and 389 cells (FXS) at day 1, and $n=498$ cells (CTRL) and 803 cells (FXS) at day 7; 40 to 100 cells per neurosphere. Data are from four independent experiments with three control and four FXS cell lines. (E to G) Representative cell responses (E), proportion of responsive cells $(F)$, and average amplitude of responses (G) to KA. Data are means \pm SEM of the experiments performed in (C) and (D). (H) Comparison of KA and AMPA responses. $n=174$ cells (CTRL) and 166 cells (FXS); 40 to 100 cells per neurosphere. Data are means \pm SEM of three independent experiments with two different control and FXS cell lines. Scale bars, $50 \mu \mathrm{m}(\mathrm{A})$ and $100 \mu \mathrm{m}(\mathrm{B}) .{ }^{*} P<0.05,{ }^{* *} P<0.01,{ }^{* * *} P<0.001$ by Fisher's exact test (F) and Student's unpaired $t$ test (G and H).

Expression levels of GluA2 are low in early developmental stages, suggesting that $\mathrm{Ca}^{2+}$ influx through CP-AMPARs contributes to the regulation of neuronal and glial development (41-44). CP-AMPARs (AMPARs lacking GluA2; herein referred to also as GluA2-lacking/ CP-AMPARs) are implicated as critical mediators of neuronal death in epilepsy, ischemia, traumatic brain injury, and neurodegenerative disorders $(42,45-47)$. Activation of CP-AMPARs in human neural progenitors induces neuronal differentiation (48), but the role of CPAMPARs in neuronal maturation defects in neurodevelopmental disorders is not yet clear.

Several rescue strategies involving the targeting of excessive protein synthesis show beneficial effects on synaptic function and behavioral phenotype in the FXS mouse model (11). However, clinical trials with appropriate pharmaceutical compounds have not been successful. To improve our understanding of the molecular mechanisms underlying the human FXS phenotype and to identify differences un- derlying the variety of the phenotype, we studied the contribution of AMPARs in impaired neurogenesis in FXS using patient-specific progenitors derived from human iPSCs. We found that FXS patientderived neuronal progenitors have reduced posttranscriptional expression of GluA2 that results in increased abundance of CP-AMPARs, leading to morphological and functional changes in subpopulations of differentiating neural progenitors. An increased differentiation of cells expressing CP-AMPARs was confirmed in mouse FXS neural progenitors and paralleled with an increased inward rectification and reduced number of GluA2 subunit-expressing cells. The results suggest a role for increased $\mathrm{Ca}^{2+}$ influx through AMPARs in the altered differentiation of neural progenitors in FXS. Although the functional changes of AMPARs appeared similar in all human cell lines studied, individual differences in control mechanisms underlying the change may exist. The data may provide new avenues for the development of optimal therapeutic interventions for individuals with FXS. 

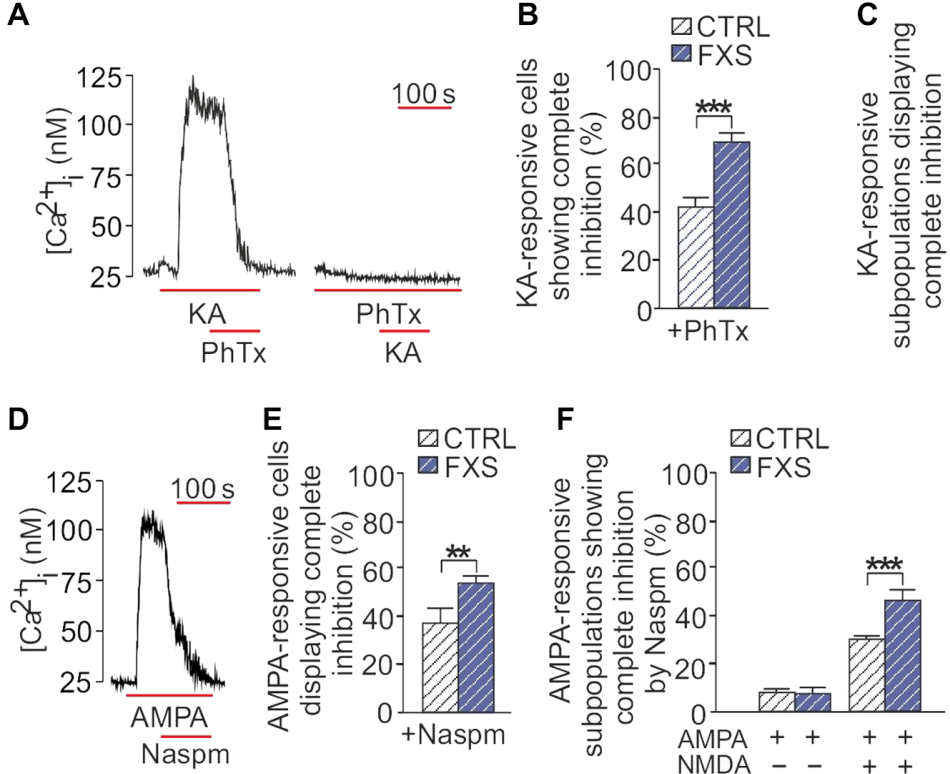

Fig. 2. Decreased GluA2 expression increases $\mathrm{Ca}^{2+}$ permeability and reduces neurite outgrowth in human neural progenitors. (A) Representative single-cell recordings showing fully inhibited $\mathrm{KA}$-induced $\left[\mathrm{Ca}^{2+}\right]_{i}$ response by philanthotoxin ( $\mathrm{PhTx}$ ). (B and $\mathbf{C}$ ) Proportion of KA-responsive cells (B) and the cell population (C) divided to cells with and without NMDA responses, showing fully inhibited responses by PhTx at day 7 of differentiation. $n=185$ cells (CTRL) and 172 cells (FXS); 40 to 100 cells per neurosphere of HEL46.11, HEL23.3, HEL100.1, and HEL69.5 cell lines. Data are means \pm SEM from two independent experiments. (D) Representative single-cell recording showing complete inhibition of AMPA-induced $\mathrm{Ca}^{2+}$ response by Naspm. (E and $\left.\mathbf{F}\right)$ Proportion of AMPA-responsive cells $(\mathrm{E})$ and the cell population (F) divided to cells with and without NMDA responses, showing fully inhibited AMPA responses by Naspm at day 7 of differentiation. $n=134$ cells (CTRL) and 156 cells (FXS); 40 to 100 cells per neurosphere of HEL46.11, HEL11.4, HEL100.2, and HEL70.3 cell lines. Data are means \pm SEM from two independent experiments. (G) Neurite length of MAP2-immunopositive neurons with and without Naspm treatment at day 1 of differentiation. $n=20$ cells in each group. Data are means \pm SEM from two independent experiments. ${ }^{*} P<0.05,{ }^{* *} P<0.01,{ }^{* * *} P<0.001$ by Fisher's exact test $(B, C, E$, and $F)$ or Mann-Whitney test (G).

\section{RESULTS}

\section{Increased differentiation of cells expressing AMPARs is seen} among human FXS iPSC-derived neural progenitors

Using intracellular calcium imaging, we assessed the effects of FMRP absence on the differentiation of glutamate-responsive cells from human FXS patient iPSC-derived neural progenitors. Four FXS and three control iPSC lines were reprogrammed from somatic cells of males diagnosed with FXS and healthy controls, respectively, and characterized as described previously (23) and summarized in fig. S1. We cultured iPSC-derived neural progenitors in neurospheres and then induced them to differentiate into neuronal cells, defined by the expression of MAP2, by withdrawing mitogen from the culture medium (Fig. 1A). In the neurosphere model, radial glia cells first appear from the differentiating neurospheres; differentiation of neuron-like cells closely follows radial glia during the first days of differentiation $(30,49)$. We have previously shown that $\left[\mathrm{Ca}^{2+}\right]_{\mathrm{i}}$ responses through mGluR5 correlate with radial glia and functional AMPA/kainate (KA) receptor expression in many cells as soon as the first day of differentiation, whereas responses to $N$-methyl-D-aspartate (NMDA) are detectable in measurable amounts of cells after 7 days of differentiation $(12,23,30,49)$. We sequentially exposed FXS and control neurospheres to (S)-3,5-dihydroxyphenylglycine (DHPG; a specific agonist of type I mGluR) and KA (an agonist of AMPA and KA receptors) at day 1 of differentiation and to KA and NMDA at day 7 of differentiation. Using Fura-2-based fluorescence recordings, we

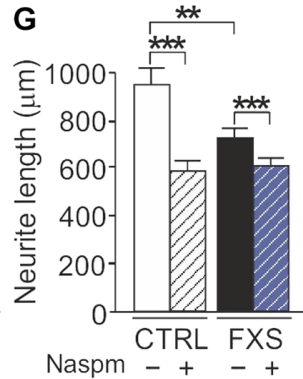

monitored $\left[\mathrm{Ca}^{2+}\right]_{\mathrm{i}}$ responses in all or most individual cells migrating out from the neurosphere (Fig. 1B) $(23,30)$. We observed that the proportion of glutamate-responsive cells was increased in FXS neurospheres when compared to controls at both time points studied (Fig. 1, C and D). These results are consistent with other studies that have shown altered differentiation kinetics in progenitor cells from FXS mouse models and FXS patients $(23,50)$.

Compared to controls at the early stages (days 1 and 7) of differentiation, the proportion of KA-responsive cells was increased and the average amplitude of $\left[\mathrm{Ca}^{2+}\right]_{i}$ responses to KA was augmented in FXS progenitors (Fig. 1, E to G). KA is a potent nondesensitizing AMPAR agonist and a rapidly desensitizing agonist for KA receptors (51). Stimulation with (S)-AMPA, the active enantiomer of AMPA, resulted in a similar FXS-specific increase in $\left[\mathrm{Ca}^{2+}\right]_{i}$ responses to that of KA (Fig. 1H), supporting the notion that KA responses were mediated via activation of AMPARs.

\section{Increased $\mathrm{Ca}^{2+}$ permeability through AMPARs reduces neurite growth in human FXS neuronal progenitors}

We examined $\mathrm{Ca}^{2+}$ permeability of AMPARs in human FXS iPSC-derived progenitors using specific AMPAR blockers. Philanthotoxin (PhTx), a CP-AMPAR blocker (52), completely abolished KA responses in differentiating neural progenitors when applied continuously to a bath solution or at the time when $\mathrm{Ca}^{2+}$ responses to KA were stable in all cells (Fig. 2A). PhTx completely blocked KA responses in a significantly larger proportion of cells in FXS neurospheres than in control neurospheres $(69 \pm 5 \%$ and $49 \pm 4 \%$, respectively; Fig. 2B). A subpopulation of cells responsive to both KA and NMDA was increased among cells in which PhTx blocked responses to KA (Fig. 2C). We confirmed the increase in CP-AMPARs in a separate set of experiments using AMPA, a specific agonist of (all) AMPARs, and Naspm trihydrochloride (Naspm), an antagonist of specifically GluA2-lacking/CP-AMPARs (53). Naspm prevented the $\left[\mathrm{Ca}^{2+}\right]_{\mathrm{i}} \mathrm{re}-$ sponse to AMPA (Fig. 2D) in a greater proportion of FXS cells than control cells ( $53.3 \pm 3 \%$ and $38.4 \pm 7 \%$, respectively) (Fig. 2E), indicating that the increased $\mathrm{Ca}^{2+}$ permeability in FXS progenitors was caused by an increased number or function of GluA2-lacking/CP-AMPARs in these cells. The proportion of cells that was responsive to both AMPA and NMDA was increased among Naspm-responsive cells in FXS progenitors (Fig. 2F), suggesting that NMDA-responsive FXS cells had especially increased $\mathrm{Ca}^{2+}$ permeability.

Neurite outgrowth is a fundamental step in the formation of proper neural network connections in the developing central nervous system. Many previous studies have shown the expression of AMPARs during early stages of neural progenitor differentiation $(31,48,54-56)$ and the involvement of AMPARs in the regulation of neurite growth $(48,57,58)$. 
A

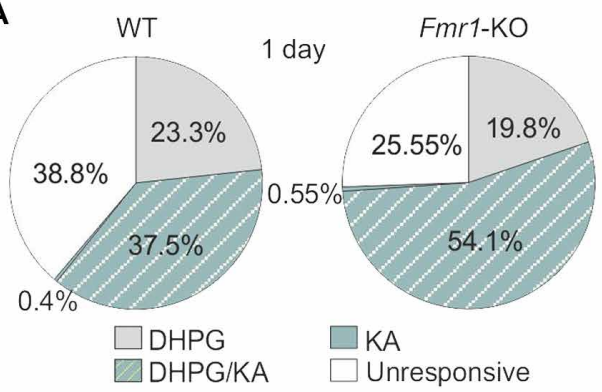

C

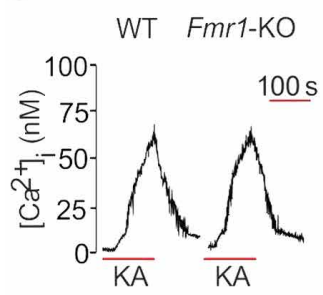

D

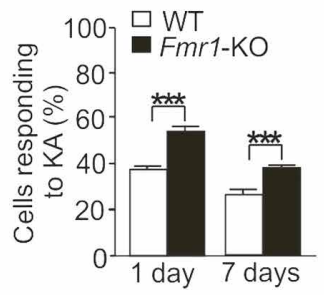

B

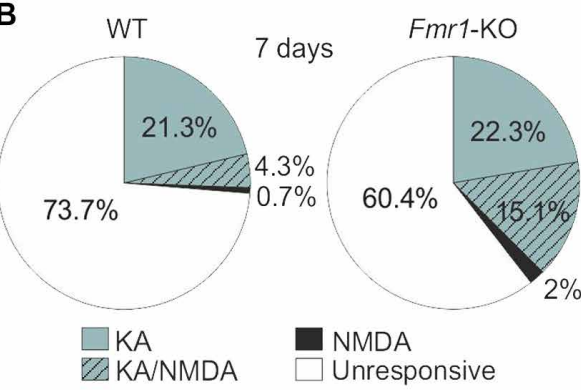

E

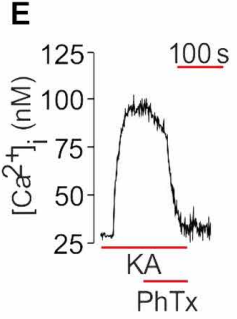

Fig. 3. Enhanced differentiation of CP-AMPAR-expressing cells in FMRP-deficient mouse neural progenitors. (A and B) Pie charts showing the proportions of cells responsive to DHPG and KA at day 1 of differentiation (A) and to KA, NMDA, and both KA and NMDA at day 7 of differentiation (B). $n=262$ cells [wild-type (WT)] and 316 cells (Fmr 1 -KO) at day 1, and $n=370$ cells (WT) and 396 cells (Fmr1-KO) at day 7; 55 to 100 cells per neurosphere. Data are from four independent experiments. (C) Representative single-cell response to KA during the time periods indicated. (D) Proportion of cells responding to KA (cells responsive/total cell number). Data are means \pm SEM of the experiments performed in (A) and (B). (E) Representative single-cell recording showing complete inhibition of $\mathrm{KA}^{-i n d u c e d}\left[\mathrm{Ca}^{2+}\right]_{\mathrm{i}}$ response by PhTx. (F) Proportion of cells fully inhibited by PhTx and Naspm in WT and Fmr1-KO neurospheres at day 7 of differentiation. $n=245$ cells $(\mathrm{WT}+\mathrm{PhTx}), 252$ cells (Fmr1-KO + PhTx), 185 cells (WT + Naspm), and 208 cells (Fmr1-KO + Naspm); 55 to 100 cells per neurosphere. Data are means \pm SEM from three independent experiments. ${ }^{* *} P<0.01$, *** $P<0.001$ by Fisher's exact test (D and F).

We tested whether GluA2-lacking/CP-AMPARs influence neurite outgrowth in human FXS neural progenitors. We observed that the neurite length of cells immunopositive for the neuronal marker MAP2 was shorter in FXS neurospheres than in controls at day 1 of differentiation (Fig. 2G), consistent with previous studies showing defects in the initial outgrowth of neurites in iPSC-derived FXS neurons $(15,17)$. Treatment with Naspm reduced neurite outgrowth in MAP2-positive cells in iPSC-derived FXS and control neurospheres (Fig. 2G) such that there was no substantial difference in neurite length between either of the Naspm-treated cell types. These results suggest that CP-AMPARs were involved in the regulation of process outgrowth of neuronal cells, as shown previously in normal human tissue-derived neural progenitors $(48,57)$.

\section{The differentiation of CP-AMPAR-expressing cells is increased in neurospheres derived from FXS model mice}

Fmr1-KO mice recapitulate the main phenotype of human FXS, including macroorchidism and many features of behavioral and cognitive phenotypes (8). By replicating the studies in neurospheres generated from the brains of embryonic Fmr1-KO mice, we confirmed the observation of increased $\mathrm{Ca}^{2+}$ permeability of AMPARs in human FXS neural progenitors. We observed that the proportion of glutamate-responsive cells (Fig. 3, A and B) and the subpopulation of KA-responsive cells (Fig. 3, C and D) was larger in Fmr1-KO than in wild-type neurospheres at days 1 and 7 of differentiation. PhTx completely blocked KA responses

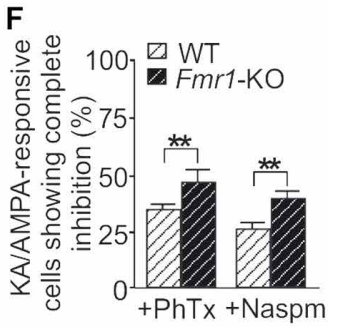

in a 1.4-fold larger proportion of cells in Fmr1-KO neurospheres than in wild-type controls (Fig. 3, E and F). Similarly, Naspm blocked AMPA responses in a 1.5-fold larger proportion of cells in Fmr1-KO neurospheres than in wild-type controls (Fig. 3F). Thus, increased expression or activity of CP-AMPARs contributed to functional changes of AMPARs similarly in Fmr1-KO mouse tissue-derived progenitors and in human iPSC-derived neural progenitors.

We validated the FXS-specific alterations observed in calcium recordings by whole-cell patch-clamp recordings. We analyzed the effects of dioxo-6-nitro1,2,3,4-tetrahydrobenzo[ $f]$ quinoxaline7-sulfonamide (NBQX; a competitive AMPAR antagonist) and Naspm (the CPAMPAR-specific channel blocker) on glutamate-evoked currents in mouse neural progenitors (Fig. 4A). The current trace evoked by glutamate in the presence of cyclothiazide was fully abolished by NBQX in both wild-type and Fmr1-KO cells at day 7 of differentiation (Fig. 4B), confirming the presence of AMPARs in differentiating neural progenitors. After the application of Naspm, glutamateevoked currents were inhibited more in Fmr1-KO progenitors than in wild-type controls (Fig. 4B), consistent with an increase in CP-AMPARs in FMRP-deficient cells. AMPARs containing a GluA2 subunit that has been RNA-edited at $\mathrm{Q} / \mathrm{R}$ site have a linear current-voltage $(I-V)$ relationship and are impermeable to divalent cations, whereas GluA2-lacking/CP-AMPARs exhibit strong inward rectification due to polyamine block $(35,36,41)$. We compared current traces at holding potentials from +40 to $-60 \mathrm{mV}$ in wild-type and Fmr1-KO cells (Fig. 4C). The rectification index $\left(I_{+40} / I_{-60}\right)$ was 3.7-fold smaller in FMRP-deficient cells than in wildtype cells (Fig. 4, D and E). The increase in inward rectification was consistent with an increase in the proportion of CP-AMPARs in FXS progenitors.

\section{The expression of AMPA subunits is altered in FMRP-deficient neural progenitors and the brain from Fmr1-KO mice}

Next, we studied correlations between functional changes of AMPARs and AMPAR subunit expression. The GluA2 subunit is essential for AMPAR $\mathrm{Ca}^{2+}$ impermeability, and its expression was decreased in human FXS progenitors when compared to controls at day 7 of differentiation (Fig. 5A). In mouse Fmr1-KO neural progenitors, the number of GluA2-expressing cells was markedly fewer, consistent with the increase in the differentiation of cells expressing CP-AMPARs in functional analysis (Fig. 5B). GRIA1 mRNA (encoding GluA1) expression was reduced in FXS iPSC-derived neurospheres when compared with controls (Fig. 5C), and GRIA1 expression did not show the normal increase during differentiation in human and mouse FXS progenitors (Fig. 5, C and D) (31). GRIA2 (encoding GluA2) expression was too 
A
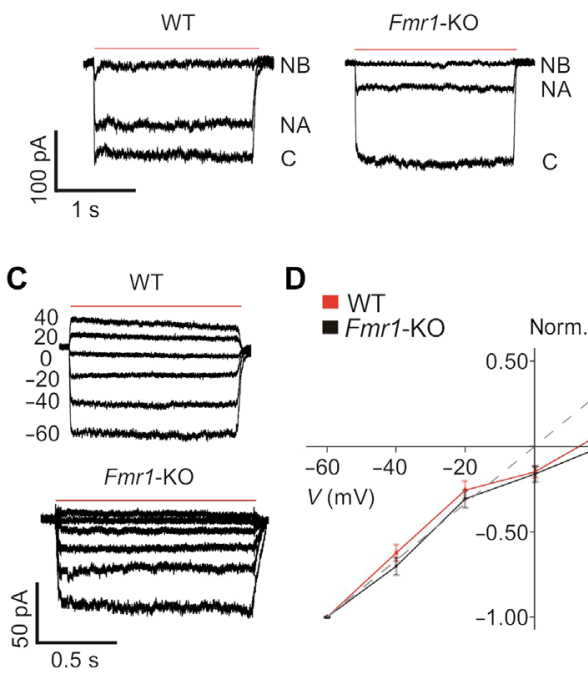

D $W T$ - WT $F$ r1-KO

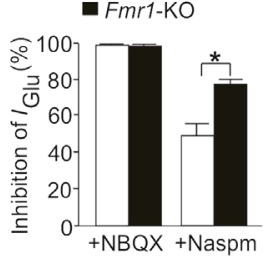

E

\section{$\square W T$}

Fmr1-KO

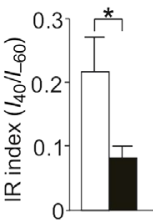

Fig. 4. Increased rectification of AMPARs in Fmr1-KO mouse progenitors. (A) Representative current traces evoked by glutamate in the presence of cyclothiazide (C) and AMPAR blockers NBQX (NB) and Naspm (NA) at day 7 of differentiation in WT and Fmr1-KO neurospheres. Horizontal bar indicates the drug application. (B) Inhibition of maximal currents ( $1 \mathrm{mM}$ glutamate and $100 \mu \mathrm{M}$ cyclothiazide) by NBQX and Naspm in the indicated cells and conditions. $n=10$ cells (WT + NBQX), 9 cells (Fmr1-KO + NBQX), 13 cells (WT + Naspm), and 10 cells (Fmr1-KO + Naspm). Data are means \pm SEM from four independent experiments. (C) Representative singlecell recording traces of $I-V$ relationship in the WT and Fmr 1 -KO neurospheres. Horizontal bar indicates the agonist application. (D) $I-V$ relationship (-60 to $40 \mathrm{mV}$ ) of normalized currents in WT (red) and Fmr1-KO (black) progenitors. The dashed line indicates the linear $I-V$ relationship. (E) Inward rectification (IR) index defined as the ratio of current amplitudes at +40 and $-60 \mathrm{mV}$ recorded from WT and Fmr1-KO cells. $n=12$ cells (WT) and 9 cells (Fmr1-KO). Data are means \pm SEM from four independent experiments. ${ }^{*} P<0.05$ by Mann-Whitney test ( $\mathrm{B}$ and $\mathrm{E}$ ).

low to be adequately analyzed in human progenitors, but we found that the expression of both Gria2 and Grial mRNAs was lower in the prefrontal cortex of adult Fmr1-KO mice than in wild-type controls (Fig. 5E).

\section{Expression of precursor and mature miR-181a is increased in human FXS progenitors}

To explore the mechanisms that lead to reduced GluA2 expression in FXS progenitors, we performed transcriptome analysis of human control and FXS neural progenitors. We compared the gene-level expression of neural progenitors generated from three control and three FXS iPSC lines. We found 669 differentially expressed genes in control and FXS progenitors at day 1 of differentiation. The expression of most (562) of these genes was greater in FXS-derived neurospheres than in control-derived neurospheres. The highly abundant genes included 79 genes that encode precursor microRNAs (miRNAs), suggesting an important role for miRNAs in the aberrant regulation of neural progenitor differentiation in FXS. The functional annotation analysis of the genes enriched in FXS progenitors showed that miRNA-regulated pathways were among the highest ranked pathways (Fig. 6A). We found a 2.3-fold increase $(P<0.0186)$ in the expression of the MIR-181A1 host gene in FXS progenitors when compared to controls. The noncoding MIR-181A1 precursor gene gives rise to miR-181a and miR-181b, the altered expression of which is linked to neuropsychiatric disorders
(59-62); for example, the expression of miR-181a and miR-181b is increased in lymphoblastoid cell lines of individuals with autism spectrum disorder (60) and that of miR-181b is increased in temporal gyrus in schizophrenia (61). It was previously reported that miR181 a targets and decreases the abundance of GluA2 transcripts and, hence, inhibits GluA2 protein activity $(59,63)$. We found that the abundance of the mature, functional forms of both miR-181a-5p and miR-181a-3p was increased in FXS progenitors at days 1 and 7 of differentiation (Fig. 6, B and C). Expression of miR-181b was not detectable in either control or FXS progenitors at these early differentiation time points studied, which is in line with a previous study that showed higher expression of miR-181b in the adult cortex relative to that in the embryonic brain (64).

\section{Intracellular calcium responses are altered in subpopulations of $\mathbf{m G l u R -}$ and iGluR-sensitive FXS progenitor cells}

To gain insight into the effects of the increase in CP-AMPARexpressing cells during FXS progenitor differentiation, we examined KA responses in subpopulations of glutamate-responsive cells in more detail. We previously showed that $\left[\mathrm{Ca}^{2+}\right]_{i}$ responses to DHPG are augmented in human and mouse FXS progenitors $(12,23)$. DHPG stimulation induces only a transient rise in $\left[\mathrm{Ca}^{2+}\right]_{i}$ in the absence of extracellular calcium, whereas a robust sustained $\mathrm{Ca}^{2+}$ response is seen in the presence of extracellular calcium, indicating that the $\mathrm{Ca}^{2+}$ rise after DHPG exposure is primarily mediated via calcium influx $(30,65)$. We observed that $\left[\mathrm{Ca}^{2+}\right]_{\mathrm{i}}$ responses to DHPG were increased in all FXS cells, including fully and partially Naspm-blocked cells and cells lacking AMPA responses, when compared to controls (Fig. 7A). In control neurospheres, responses to DHPG were smaller in cells totally inhibited by Naspm when compared to responses in cells only partially inhibited, which was not seen in FXS neurospheres (Fig. 7A). This difference between wild-type and FXS progenitors could reflect alterations of differentiating progenitor subpopulations. At day 7 of differentiation, KA responses were augmented in FXS cells responsive to DHPG or NMDA (or both) but not in cells that were not responsive to DHPG or NMDA (or both) (Fig. 7B). Although the FXSspecific increase in the differentiation of CP-AMPAR-expressing cells was similar in human and mouse neurospheres, the average amplitude of $\left[\mathrm{Ca}^{2+}\right]_{\mathrm{i}}$ responses to AMPA was not abnormally increased in Fmr1-KO progenitors as in human FXS progenitors (Fig. 7C). The spike amplitude of $\left[\mathrm{Ca}^{2+}\right]_{\mathrm{i}}$ responses to KA is similarly identical in wild-type and FMRP-deficient mouse progenitors (23). We previously reported differential responses to mGluR5 antagonism in neural progenitors derived from human iPSCs and mouse brain tissue lacking FMRP (23). The differences of responses likely reflect progenitor type-dependent differences, which are caused by species-specific properties at the differentiation time points studied. Together, the data are consistent with alterations of glutamate-responsive cell populations and differences in homeostatic $\mathrm{Ca}^{2+}$ responses during differentiation of FXS progenitors.

\section{DISCUSSION}

The present results demonstrate that calcium signaling via AMPARs is affected in human FXS neural progenitors and that FXS progenitors generate more cells expressing CP-AMPARs than controls. This suggests that functional alterations of AMPARs affect neuronal differentiation and contribute to aberrances of neural circuit formation and function in FXS. The increase in the $\mathrm{Ca}^{2+}$ permeability of AMPARs in 


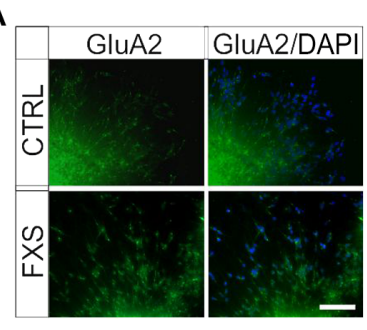

C

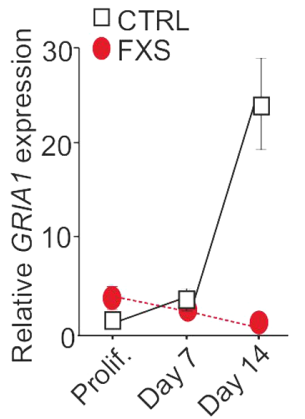

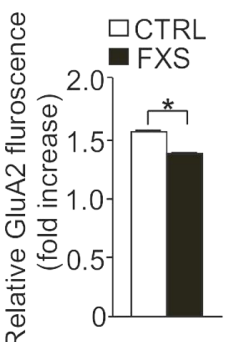

D
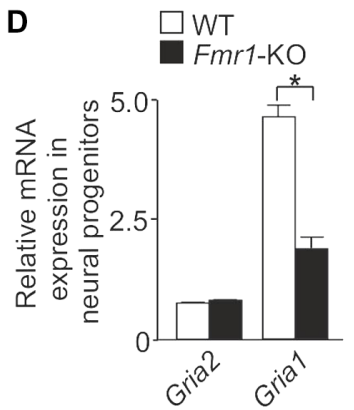

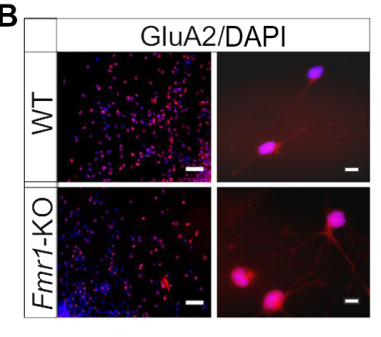

E
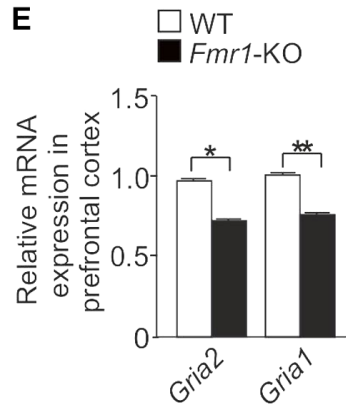

Fig. 5. Altered expression of GluA1 and GluA2 in human and mouse FXS neural progenitors. (A) Immunofluorescence images showing GluA2 (green) and relative GluA2 protein expression in human neural progenitors at day 7 of differentiation ( $n=100$ cells per group). Data are means \pm SEM of two independent experiments with two different control and FXS cell lines. (B) Representative images and analysis of GluA2 staining (red) in mouse neural progenitors at day 7 of differentiation. Data are means \pm SEM of two independent experiments ( $n=100$ cells per group). (C) Relative mRNA expression of GRIA1 in proliferating (Prolif.) and differentiated (at days 7 and 14) human neural progenitors. Data are means \pm SEM of three independent experiments performed in triplicate; $n=3$ cell lines (CTRL) and 3 cell lines (FXS). (D and E) Relative mRNA expression of Gria1 and Gria2 in (D) mouse neural progenitors at day 7 of differentiation and (E) the prefrontal cortex of Fmr1-KO and WT mice ( $n=8$ brain samples each). Data are means \pm SEM of at least three independent experiments performed in triplicate. Scale bars, $100 \mu \mathrm{m}(\mathrm{A})$ and $100 \mu \mathrm{m}(10 \mathrm{X})$ and $10 \mu \mathrm{m}(63 \times)$ (B). ${ }^{*} P<0.05,{ }^{* *} P<0.01,{ }^{* * *} P<0.001$ by Mann-Whitney test (A, D, and E) or Fisher's exact test (B).

FXS progenitors is caused by reduced expression of the GluA2 subunit, which was linked to miRNA-based posttranscriptional mechanisms by showing an increase in miR-181a expression. The normal increase in GRIA1 mRNA expression was missing during early progenitor differentiation in FXS cells, consistent with the maturation defect of AMPARs. We observed identical FXS-specific increase in AMPA-responsive cells in human and mouse progenitors and showed that the increase in the differentiation of cells lacking GluA2 reflected augmented inward rectification in neural progenitors derived from Fmr1-KO mice. AMPARs lacking GluA2 were expressed particularly in cells responsive to NMDA. CP-AMPARs promote neuronal differentiation (48), and the increase in cells coexpressing CP-AMPARs and NMDA receptors correlated with enhanced differentiation of NMDAresponsive cells in FXS neurospheres. Blocking GluA2-lacking AMPARs reduced neurite growth of differentiating neurons, supporting an important contribution of functional properties of AMPAR to abnormalities of neurite growth in FXS progenitors (58).

We identified defects in human FXS progenitor differentiation in glutamate-responsive cells during very early phases of neuronal cell differentiation. FMRP is an RNA binding protein that regulates translation of transcripts encoding several developmental genes in neural progenitors. The absence of FMRP has been shown to affect signaling pathways that control neuronal differentiation and migration $(19,20,66)$. Alterations of gene expression in human FXS iPSCderived progenitors have been shown to associate with epigenetic modifications involved in neurogenic defects $(20,21)$, but disease- brain. In neural progenitors, alterations 列 creased $\mathrm{Ca}^{2+}$ influx via AMPARs renders FXS cells more susceptible to excitotoxicity (46). Increased vulnerability of FXS neurons could interfere with the establishment of normal neocortical circuits, contributing to the excitatory and inhibitory imbalance in the FXS brain. Previously aberrant $\mathrm{Ca}^{2+}$-dependent mechanisms have been shown to be involved in hyperexcitability of the neocortical circuits in the FXS mouse brain (29). Alterations in the maturation of AMPAR responses could influence neuronal migration and contribute to the delayed positioning of glutamatergic neurons to the cortical plate as observed in the Fmr1-KO mouse brain (67). CP-AMPAR-mediated changes in control of neurite growth $(48,57)$ might play a role in the abnormalities observed in the morphological transformation of migrating cells in the developing cortex of the FXS mouse (67).

The subunit composition of AMPARs is tightly regulated in a manner dependent on cell type and developmental state $(68,69)$. Changes of AMPAR subunits are involved in the developmental switch of CPAMPARs in neocortical pyramidal neurons (41) and synapse-specific expression of CP-AMPARs in the neocortex (44). AMPARs lacking GluA2 are transiently expressed on cerebral radial glia and non-neuronal precursors, including white matter elements $(39,40)$. We used AMPARspecific agonists and antagonists to show that reduced GluA2 subunit protein expression correlated with the increase in CP-AMPARexpressing cells in functional analysis of FXS neurospheres at the presynaptic stage. FXS progenitors also expressed less GRIA1 mRNA. GluA1 is a regulator of neuronal maturation, and its absence reduces 


\section{A}

Pathways affected in FXS progenitors

miR-targeted genes in lymphocytes miR-targeted genes in muscle cell miR-targeted genes in epithelium Focal adhesion-PI3K-Akt-mTOR Nuclear receptors VEGFA-VEGFR2 signaling Circadian rhythm related genes Focal adhesion EGF/EGFR signaling MAPK signaling Mesodermal commitment Endoderm differentiation Insulin signaling Ectoderm differentiation Brain-derived neurotrophic factor signaling Sudden infant death syndrome (SIDS) miR-targeted genes in squamous cell miR-targeted genes in leukocytes

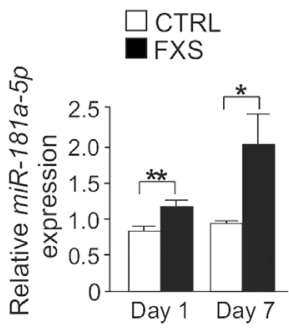

Number of up-regulated genes
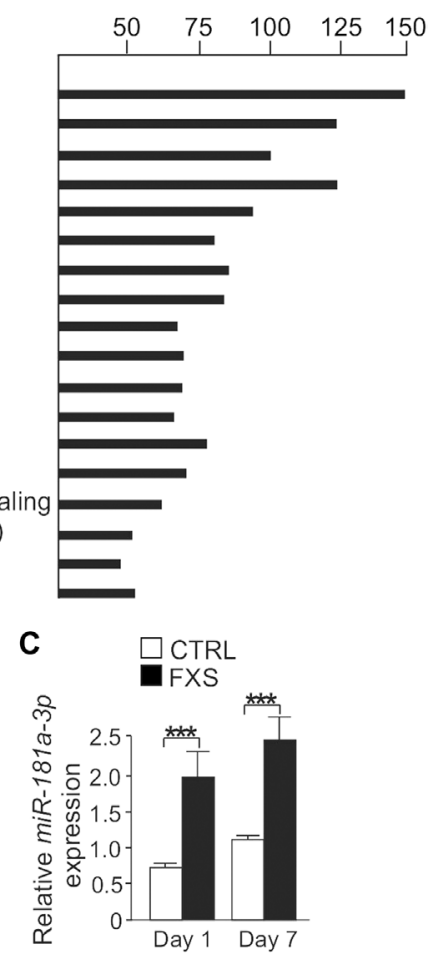

Fig. 6. Expression profiling and increased $\mathbf{m i R}$-181a expression in FXS progenitors. (A) Highest ranked pathways of genes up-regulated in human FXS iPSC-derived neural progenitors compared with controls at day 1 of differentiation in the transcriptome analysis. $n=3$ cell lines each. (B and C) Relative expression of miR-181a-5p (B) and miR-181a-3p (C) in human neural progenitors at days 1 and 7 of differentiation. Data are means \pm SEM of three independent experiments performed in triplicate; $n=$ 3 cell lines each. ${ }^{*} P<0.05,{ }^{* *} P<0.01,{ }^{* *} P<0.001$ by Mann-Whitney test ( $\mathrm{B}$ and $\mathrm{C}$ ).

dendritic growth (58), consistent with the differentiation defect of FMRP-deficient progenitors. Telias et al. (18) have shown that human embryonic stem cell-derived FXS neurons are unable to discharge trains of action potentials, display less developed inward and outward currents, and lack spontaneous activity. Impaired synaptic delivery of GluA1-containing AMPARs is implicated in defects of synaptic plasticity in Fmr1-KO mice (70). Guo et al. (58) recently reported that FMRP promotes GluA1 membrane delivery and induces maturation of neurons additively with its autosomal paralog FXR2P. Reduced Gria1 and Gria 2 expression in the prefrontal cortex of Fmr1-KO mice was in agreement with reduced protein expression of both GluA1 and GluA2 in the somatosensory cortex of these mice shown previously (71). Reduced AMPAR subunits reflect alterations of AMPAR function, which is consistent with a role for GluA2 in dysfunction of cortical neurons in FXS. However, putative cell type-specific alterations of GluA2 expression affecting AMPAR function remain to be studied in the FXS brain.

Direct interaction of FMRP with either GluA1 or GluA2 mRNAs has not been found (10). The AMPAR gene Gria2 is one of the transcriptionally responsive target genes of the repressor element 1 silencing transcription factor (REST), which is dysregulated in FXS iPSC-derived neurons (21). REST is involved in the regulation of the pool and timing of neuronal differentiation to different neuronal lineages (72), and REST-mediated epigenetic modifications may contribute to reduced GluA2 expression in FXS progenitors. We found that the absence of FMRP affects the expression of genes encoding precursor miRNAs during early neural progenitor differentiation. FXS progenitors expressed abnormally high levels of the MIR-181A1 host gene, which gives rise to miR-181a and miR-181b $(59,60,63)$. Increased expression of miR-181a can directly regulate GluA2 expression $(59,63)$ and may reduce GluA2 protein expression in FXS progenitors. Given the technical limitations with the human neural progenitors used in the study, direct effects of miR-181a on GluA2 and functional AMPAR responses were not tested. However, on the basis of the present results at the early differentiation of neural progenitors, alterations of the miRNA gene expression provide a regulatory mechanism for the GluA2 subunit protein expression in FXS progenitors.

The mGluR theory of FXS postulates that exaggerated downstream consequences of type I mGluR activation cause the FXS phenotype (2). Intracellular calcium responses to $\mathrm{mGluR} 1 / 5$ activation are augmented in FXS neural progenitors (23), suggesting that mGluR5-mediated disturbances are involved in the early differentiation defects of FXS progenitors. We found that increased $\mathrm{Ca}^{2+}$ influx through CP-AMPARs might modify the responses to glutamate receptor activation in distinct cell populations. The proportion of cells responsive to NMDA was particularly increased among cells expressing GluA2-lacking AMPARs, whereas responses to KA were not altered in a subpopulation of cells unresponsive to DHPG, NMDA, or both. NMDA receptors largely mediate the cytotoxic effects of glutamate, whereas type I mGluRs have protective roles in neuronal cells (73). Thus, coordinated regulation of functional responses to activation of ionotropic glutamate receptors (iGluRs) and mGluRs could provide a selective system to control differentiation of neural progenitors.

Altered differentiation of FXS iPSC-derived neural progenitors to glutamatergic lineages is consistent with impaired maturation of glutamatergic neurons and their signaling identified during the development of the Fmr1-KO mouse brain $(1,13,14)$. Delayed developmental progression from exclusively NMDA to both AMPAR and NMDA receptor-mediated responses indicates functional maturation aberrances of neurons expressing iGluRs in the brain of Fmr1-KO mice (1). We showed that the absence of FMRP causes similar functional changes of AMPAR channels in neural progenitors derived from FXS mouse brain tissue and human iPSCs generated from several FXS males. Alternative splicing and miRNA regulation have recently been shown to play fundamental roles in neural development and in the establishment and function of neuronal networks. Our results provide evidence that abnormal expression of noncoding genes contributes to functional changes of FXS neural progenitors. The data indicate that patientspecific iPSCs provide a useful tool for further studies investigating neurobiology and for treatment responses in FXS. Dysregulation of CPAMPARs is implicated in a variety of neuropathologies, including epilepsy, ischemia, traumatic injury, and neurodegeneration $(42,45-47)$. The present study adds FXS to the group of diseases involving CPAMPARs. Alterations of $\mathrm{Ca}^{2+}$ signaling similar to those observed in FXS are also found in models of FMR1 premutation, which associates with the neurodegenerative disorder, FXS-associated tremor/ataxia syndrome $(16,74)$. Moreover, recent evidence that FMRP is a substrate in many neuropsychiatric disorders $(75,76)$ may indicate broader implications for the present results.

\section{MATERIALS AND METHODS}

\section{Human iPSC cultures and neuronal differentiation}

The research using human iPSCs was approved by the Ethical Committee of the Hospital District of Helsinki and Uusimaa. Written 

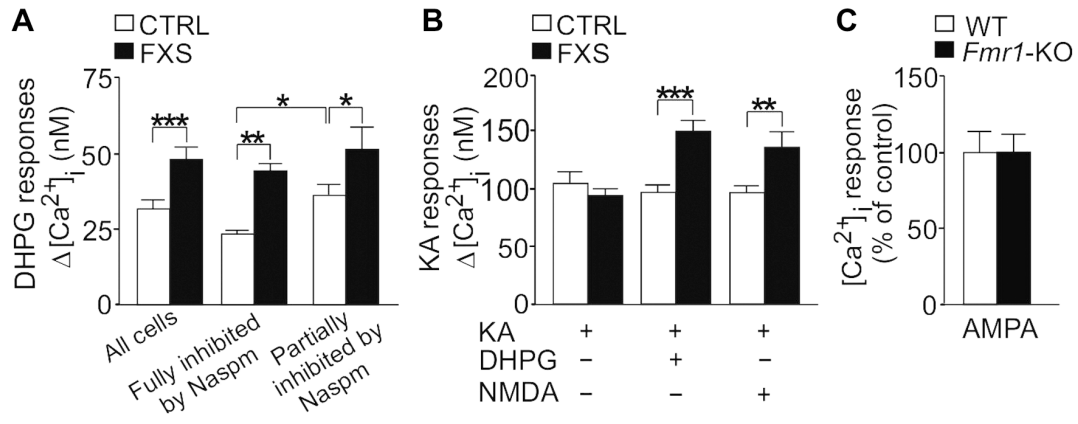

Fig. 7. Intracellular calcium responses to KA/AMPA in subpopulations of glutamate-responsive FXS progenitors. (A) Average amplitude of $\left[\mathrm{Ca}^{2+}\right]_{\mathrm{i}}$ responses to DHPG in subpopulations of cells responsive to AMPA blocked totally and partially with Naspm in human neural progenitors at day 7 of differentiation. $n=134$ cells (CTRL) and 156 cells (FXS) from HEL46.11, HEL11.4, HEL100.2, and HEL70.3 cell lines. Data are means \pm SEM of two independent experiments. (B) Average amplitude of responses to KA in subpopulations of cells responsive to KA, DHPG, and NMDA in human neural progenitors at day 7 of differentiation. $n=498$ cells (CTRL) and 803 cells (FXS). Data are means \pm SEM of four independent experiments with three control and four FXS cell lines. (C) Amplitude of $\left[\mathrm{Ca}^{2+}\right]_{\mathrm{i}}$ response to AMPA in mouse neural progenitors at day 7 of differentiation. $n=185$ cells (WT) and 208 cells ( $F m r 1-K O$ ); 55 to 100 cells per neurosphere. Data are means \pm SEM from three independent experiments. ${ }^{*} P<0.05,{ }^{* *} P<0.01,{ }^{* * *} P<0.001$ by oneway analysis of variance (ANOVA) with post hoc Tukey analysis (A) or Student's unpaired $t$ test (B).

informed consent was provided to obtain human samples. The four FXS iPSC lines (HEL100.1, HEL100.2, HEL69.5, and HEL70.3) and three control cell lines (HEL46.11, HEL23.3, and HEL11.4) used in the study were previously characterized $(23,77)$ and are summarized in fig. S1. Several iPSC lines were reprogrammed from somatic cells of each male using Sendai virus (CytoTune-iPS Sendai Reprogramming Kit, Gibco, Life Technologies Ltd.) at the Biomedicum Stem Cell Center (University of Helsinki, Finland). Cells were grown as a monolayer on Matrigel-coated plates (BD Biosciences) in Essential 8 (E8) medium containing E8 supplement (both from Gibco, Life Technologies Ltd.). Cultures were maintained at $37^{\circ} \mathrm{C}$ and $5 \% \mathrm{CO}_{2}$ in a humidified incubator. All cell cultures were tested regularly to be free from mycoplasma contamination using Mycoplasma detection kit (MycoAlert, Lonza Group Ltd.). The culture medium was changed every other day, and the cell colonies were passaged every 4 to 5 days using $0.5 \mathrm{mM}$ EDTA (Invitrogen, Life Technologies Ltd.) in phosphate-buffered saline (PBS).

Neural progenitors derived from iPSC lines were cultured in neurospheres $(23,78)$. Initially, clusters of iPSCs were cultured to form embryoid bodies (EBs) on low-adherent plates in neuronal differentiation medium containing Dulbecco's modified Eagle's medium (DMEM)/F-12, Neurobasal (1:1), B27 supplement, 2 mM GlutaMAX, N2 supplement (all from Gibco, Life Technologies Ltd.), and basic fibroblast growth factor (bFGF; $20 \mathrm{ng} / \mathrm{ml}$; PeproTech). To optimize cell survival and neuronal differentiation, Y-27632 dihydrochloride $(10 \mu \mathrm{m}, \mathrm{Abcam})$ was added in the culture medium on the first day. After the first week, the medium was replaced every 2 to 3 days with fresh culture medium. EBs were passaged by manual trituration about once a week. After 6 weeks, neurospheres (average size, about 200 to $250 \mu \mathrm{m}$ ) were differentiated for 1, 7, and 14 days on poly-D-lysine/ laminin (Sigma-Aldrich)-coated cover glasses in the culture medium without mitogens. Neurospheres were treated with Naspm $(10 \mu \mathrm{M})$ after plating in neuronal differentiation medium and allowed to differentiate for 1 day.

\section{Mice}

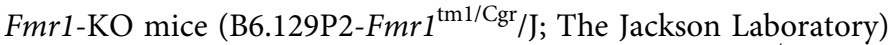
were maintained in the C57BL/6JOlaHsd substrain. $\mathrm{Fmrl}^{-/+}$female $15 \mathrm{mM}$ Hepes, penicillin $(100 \mathrm{U} / \mathrm{ml})$, streptomycin $(100 \mathrm{U} / \mathrm{ml})$ (all from Sigma-Aldrich), and mitogens bFGF ( $10 \mathrm{ng} / \mathrm{ml})$ and epidermal growth factor $\left(20 \mathrm{ng} / \mathrm{ml}\right.$; PeproTech). Cultures were maintained at $37^{\circ} \mathrm{C}$ and $5 \%$ $\mathrm{CO}_{2}$ in a humidified incubator. Each culture was genotyped and tested to be free from mycoplasma contamination. The culture medium was refreshed twice a week, and the mitogens were added three times per week. For differentiation, neurospheres (middle-sized 200- to 250- $\mu \mathrm{m}$ spheres) were plated on poly-DL-ornithine (Sigma-Aldrich)-coated cover glasses in the culture medium without mitogens. Growth factors were always added to cultures a day before the initiation of the differentiation for 1 or 7 days.

\section{Calcium imaging}

Calcium imaging was performed as previously described $(12,79)$. For experiments, 15 to 20 mouse and human neurospheres were plated on poly-DL-ornithine- and poly-D-lysine/laminin-coated 25 -mm cover glasses, respectively. At the indicated time points of differentiation, cells were loaded with Fura-2 by incubating them in the dark at $37^{\circ} \mathrm{C}$ for 20 min in Hepes-buffered medium (HBM; pH 7.4) containing $4 \mu \mathrm{M}$ Fura-2 acetoxymethyl ester (Molecular Probes) dissolved in $4 \mathrm{mM}$ dimethyl sulfoxide (Sigma-Aldrich). The HBM contained $137 \mathrm{mM} \mathrm{NaCl}$, $5 \mathrm{mM} \mathrm{KCl}, 0.44 \mathrm{mM} \mathrm{KH}_{2} \mathrm{PO}_{4}, 4.2 \mathrm{mM} \mathrm{NaHCO}_{3}, 2 \mathrm{mM} \mathrm{CaCl}_{2}, 0.5 \mathrm{mM}$ $\mathrm{MgCl}_{2}, 10 \mathrm{mM}$ Hepes, and $10 \mathrm{mM}$ glucose (all from Sigma-Aldrich). Cover glasses were then attached to a heat-controlled perfusion chamber on the microscope $(20 \times$ objective, Nikon). Cells were perfused at $2 \mathrm{ml} / \mathrm{min}$ in $\mathrm{HBM}$ at $37^{\circ} \mathrm{C}$ and excited by alternating wavelengths of 340 and $380 \mathrm{~nm}$ using narrow-band excitation filters. Light emission was measured through a $430-\mathrm{mm}$ dichroic mirror and a $510-\mathrm{nm}$ barrier filter with an integrating charge-coupled device (CCD) camera (COHU/Olympus). Perimeters of neuronal somata were outlined as regions of interest (ROIs), and $\left[\mathrm{Ca}^{2+}\right]_{\mathrm{i}}$ rise in each ROI was recorded after agonist exposures. All agonists were diluted in HBM and supplied through the perfusion system. An image (ratio, 340/380 nm) was acquired each second; up to 40 to 100 cells were analyzed. The images were collected and saved for later analysis using InCyt 4.5 software (Intracellular Imaging Inc.) and Origin 6.0 (OriginLab Corp.) or CellR software (Olympus). Changes $(\Delta)$ of $\left[\mathrm{Ca}^{2+}\right]_{i}$ were determined 
after background subtraction. The following glutamate receptor agonists and antagonists were used: $10 \mu \mathrm{M}$ DHPG (Abcam), $50 \mu \mathrm{M} \mathrm{KA}$ (Tocris Bioscience), $50 \mu \mathrm{M}$ AMPA (Tocris Bioscience), $5 \mu \mathrm{M}$ PhTx (Tocris Bioscience), $10 \mu \mathrm{M}$ Naspm (Tocris Bioscience), $50 \mu \mathrm{M}$ NMDA (Sigma-Aldrich), and $10 \mu \mathrm{M}$ glycine (Sigma-Aldrich).

\section{Patch-clamp electrophysiology}

Whole-cell patch-clamp recordings were performed with Axopatch $1 \mathrm{~B}$ patch clamp amplifier and pClamp 10 software (Molecular Devices) at a holding potential of $-70 \mathrm{mV}$. Electrodes were pulled from borosilicate glass capillaries (World Precision Instruments) and had a resistance of 3 to 4 megohms when filled with an internal solution containing $100 \mathrm{mM} \mathrm{N}$-methyl-D-glucamine, $100 \mathrm{mM} \mathrm{CH}_{3} \mathrm{SO}_{3} \mathrm{H}, 40 \mathrm{mM}$ $\mathrm{CsF}, 10 \mathrm{mM} \mathrm{MgCl}_{2}, 10 \mathrm{mM}$ Hepes, and $5 \mathrm{mM}$ EGTA (pH adjusted to 7.4 with $\mathrm{CsOH}$ and osmolarity adjusted to 305 mosmol). Cells were continuously perfused with recording solution containing $150 \mathrm{mM}$ $\mathrm{NaCl}, 2.5 \mathrm{mM} \mathrm{KCl}, 2.5 \mathrm{mM} \mathrm{CaCl}_{2}, 1 \mathrm{mM} \mathrm{MgCl}_{2}, 10 \mathrm{mM}$ glucose, and 10 mM Hepes (pH 7.4; 320 mosmol). L-Glutamate, NBQX, and Naspm were diluted to recording solution and applied to the cells using a piezo-driven applicator (Siskiyou Piezo Switcher, Siskiyou Corporation). All recordings were performed in the presence of cyclothiazide to prevent rapid AMPAR desensitization. Drug applications lasted for $2 \mathrm{~s}$, each drug application was repeated twice, and traces were averaged for analysis. In $I$ - $V$ curve recordings, spermine (Sigma-Aldrich) was added to the internal solution to enhance the polyamine block of CP-AMPARs. Recordings were performed at a sampling rate of $5 \mathrm{kHz}$ and low-pass Bessel-filtered at $1 \mathrm{kHz}$. Analysis was performed using Clampfit 10.2 software (Molecular Devices) and Prism 4.02 software (GraphPad). The following glutamate receptor agonists and antagonists were used: $1 \mathrm{mM}$ L-glutamate (Sigma-Aldrich), $100 \mu \mathrm{M}$ cyclothiazide (Tocris Bioscience), $10 \mu \mathrm{M}$ NBQX (Sigma-Aldrich), and $10 \mu \mathrm{M}$ Naspm.

\section{Immunocytochemistry}

For immunocytochemistry of human iPSCs and neural progenitors, cells were fixed with $4 \%$ paraformaldehyde in PBS for $10 \mathrm{~min}$ at room temperature (RT). After blocking nonspecific staining in PBS containing $10 \%$ normal goat serum (NGS), 1\% bovine serum albumin (BSA), and $0.1 \%$ Triton X-100 for $45 \mathrm{~min}$ at RT, cells were incubated with the primary antibodies overnight at $4^{\circ} \mathrm{C}$. Primary antibodies were diluted in PBS containing 1\% NGS, $1 \%$ BSA, and $0.1 \%$ Triton $\mathrm{X}-100$. All primary antibodies used in the study are commercially available and well characterized. We used primary antibodies recognizing TRA-1-60 (1:500, MA1-023; Thermo Fisher Scientific), OCT4 (1:500, C30A3; Cell Signaling Technology), SOX2 (1:25, MAB2018; R\&D Systems), Nestin (1:50, SC-20978; Santa Cruz Biotechnology), SSEA3 (1:100, MAB4303; Millipore), MAP2 (1:500, MAB364; Millipore), and GluA2 (1:100, MABN71; Millipore). Secondary antibodies were applied in PBS containing 1\% BSA for $45 \mathrm{~min}$ at RT. Secondary antibodies were Alexa Fluor 488 mouse (1:500, A21042; Life Technologies Ltd.), Alexa Fluor 488 rabbit (1:2000, A11008; Invitrogen), Alexa Fluor 488 rat (1:500, A21212; Life Technologies Ltd.), and Alexa 568 mouse (1:5000, A11004; Invitrogen). After final washes, the cell nuclei were counterstained with Vectashield mounting medium containing DAPI (Vector Laboratories).

\section{Image analysis}

Fluorescent-stained cells were viewed, and images were obtained with an epifluorescence microscope equipped with a Hamamatsu Orca R2 monochrome CCD camera (Axio Imager, Zeiss). The images were processed using ZEN software (Zeiss). The proportion of cells was measured by dividing the number of immunopositive cells by the number of DAPI-positive cells in the whole migration area. Fluorescence intensity was quantified using ImageJ software as described previously (80). Corrected total cell fluorescence (CTCF) was measured as follows: CTCF $=$ Integrated density - (Area of selected cell ${ }^{*}$ Mean fluorescence of background value).

\section{RNA extraction and quantitative RT-PCR}

Total RNA was extracted from neural progenitors and mouse prefrontal cortex tissue using the RNA Purification Kit (Norgen Biotek Corp.) according to the manufacturer's instructions. Complementary DNA (cDNA) was synthesized from $1 \mu \mathrm{g}$ of RNA using the Transcriptor First Strand cDNA Synthesis Kit (Roche). Quantitative reverse transcription polymerase chain reaction (RT-PCR) was performed using the SYBR Green I Kit and LightCycler 480 II RealTime PCR System (Roche Diagnostics). For miRNA assays, $100 \mathrm{ng}$ of RNA was used to synthesize cDNA using the TaqMan microRNA Reverse Transcription Kit, and quantitative PCR was performed using TaqMan Universal Master Mix II (both from Life Technologies Ltd.). The primers used to amplify the specific cDNA regions of transcripts are appended (table S1). Each sample was run in triplicate with melting curve analysis to detect primer dimer artifacts. Data were analyzed using LightCycler 480 software (Roche) by the second derivative maximum method determining the threshold cycle $\left(C_{\mathrm{t}}\right)$. Relative quantities of GRIA1, GRIA2, and miR-181a expression were calculated with the $\Delta \Delta C_{\mathrm{t}}$ method (81). Expression of GAPDH and $m i R-191$ was used to normalize the data.

\section{Transcriptional profiling}

For the Affymetrix Clariom D Human array (Thermo Fisher Scientific), $100 \mathrm{ng}$ of total RNA was processed with a GeneChip WT PLUS reagent kit (Thermo Fisher Scientific) according to the sample preparation guide. Affymetrix Expression Console Software was used for data analysis. The data were processed using signal space transformation-robust multichip analysis that includes background reduction and intensity normalization.

\section{Statistical analysis}

Data are means \pm SEM. Statistical comparisons were performed with two-tailed Student's unpaired $t$ test, Fisher's exact test, one-way ANOVA followed by post hoc Tukey analysis, and Mann-Whitney test using IBM SPSS analysis software. A $P$ value of $<0.05$ was considered statistically significant.

\section{SUPPLEMENTARY MATERIALS}

www.sciencesignaling.org/cgi/content/full/11/513/eaan8784/DC1 Fig. S1. Characterization of human iPSC lines.

Table S1. Primer sequences used in real-time quantitative PCR.

\section{REFERENCES AND NOTES}

1. E. G. Harlow, S. M. Till, T. A. Russell, L. S. Wijetunge, P. Kind, A. Contractor, Critical period plasticity is disrupted in the barrel cortex of FMR1 knockout mice. Neuron 65, 385-398 (2010).

2. M. F. Bear, K. M. Huber, S. T. Warren, The mGluR theory of fragile $X$ mental retardation. Trends Neurosci. 27, 370-377 (2004).

3. J. R. Gibson, A. F. Bartley, S. A. Hays, K. M. Huber, Imbalance of neocortical excitation and inhibition and altered UP states reflect network hyperexcitability in the mouse model of fragile X syndrome. J. Neurophysiol. 100, 2615-2626 (2008). 
4. G. J. Bassell, S. T. Warren, Fragile $X$ syndrome: Loss of local mRNA regulation alters synaptic development and function. Neuron 60, 201-214 (2008).

5. J. T. Goncalves, J. E. Anstey, P. Golshani, C. Portera-Cailliau, Circuit level defects in the developing neocortex of Fragile X mice. Nat. Neurosci. 16, 903-909 (2013).

6. Y. Zhang, A. Bonnan, G. Bony, I. Ferezou, S. Pietropaolo, M. Ginger, N. Sans, J. Rossier, B. Oostra, G. LeMasson, A. Frick, Dendritic channelopathies contribute to neocortical and sensory hyperexcitability in Fmr1 ${ }^{-/ y}$ mice. Nat. Neurosci. 17, 1701-1709 (2014).

7. R. Hagerman, G. Hoem, P. Hagerman, Fragile $X$ and autism: Intertwined at the molecular level leading to targeted treatments. Mol. Autism 1, 12 (2010).

8. P. Jin, S. T. Warren, Understanding the molecular basis of fragile $X$ syndrome. Hum. Mol. Genet. 9, 901-908 (2000).

9. A. J. Verkerk, M. Pieretti, J. S. Sutcliffe, Y.-H. Fu, D. P. Kuhl, A. Pizzuti, O. Reiner, S. Richards, M. F. Victoria, F. Zhang, B. E. Eussen, G.-J. B. van Ommen, L. A. J. Bloden, G. J. Riggins, J. L. Chastain, C. B. Kunst, H. Galijaard, C. T. Caskey, D. L. Nelson, B. A. Oostra, S. T. Warren, Identification of a gene (FMR-1) containing a CGG repeat coincident with a breakpoint cluster region exhibiting length variation in fragile $X$ syndrome. Cell 65, 905-914 (1991).

10. J. C. Darnell, S. J. Van Driesche, C. Zhang, K. Y. Hung, A. Mele, C. E. Fraser, E. F. Stone, C. Chen, J. J. Fak, S. W. Chi, D. D. Licatalosi, J. D. Richter, R. B. Darnell, FMRP stalls ribosomal translocation on mRNAs linked to synaptic function and autism. Cell 146, 247-261 (2011).

11. J. D. Richter, G. J. Bassell, E. Klann, Dysregulation and restoration of translational homeostasis in fragile X syndrome. Nat. Rev. Neurosci. 16, 595-605 (2015).

12. M. Castrén, T. Tervonen, V. Kärkkäinen, S. Heinonen, E. Castrén, K. Larsson, C. E. Bakker, B. A. Oostra, K. Åkerman, Altered differentiation of neural stem cells in fragile $\mathrm{X}$ syndrome. Proc. Natl. Acad. Sci. U.S.A. 102, 17834-17839 (2005).

13. T. A. Tervonen, V. Louhivuori, X. Sun, M.-E. Hokkanen, C. F. Kratochwil, P. Zebryk, E. Castrén, M. L. Castrén, Aberrant differentiation of glutamatergic cells in neocortex of mouse model for fragile X syndrome. Neurobiol. Dis. 33, 250-259 (2009).

14. R. Saffary, Z. Xie, FMRP regulates the transition from radial glial cells to intermediate progenitor cells during neocortical development. J. Neurosci. 31, 1427-1439 (2011).

15. S. D. Sheridan, K. M. Theriault, S. A. Reis, F. Zhou, J. M. Madison, L. Daheron, J. F. Loring, S. J. Haggarty, Epigenetic characterization of the FMR1 gene and aberrant neurodevelopment in human induced pluripotent stem cell models of fragile $X$ syndrome. PLOS ONE 6, e26203 (2011).

16. J. Liu, K. A. Kościelska, Z. Cao, S. Hulsizer, N. Grace, G. Mitchell, C. Nacey, J. Githinji, J. McGee, D. Garcia-Arocena, R. J. Hagerman, J. Nolta, I. N. Pessah, P. J. Hagerman, Signaling defects in iPSC-derived fragile X premutation neurons. Hum. Mol. Genet. 21, 3795-3805 (2012).

17. M. E. Doers, M. T. Musser, R. Nichol, E. R. Berndt, M. Baker, T. M. Gomez, S. C. Zhang, L. Abbeduto, A. Bhattacharyya, iPSC-derived forebrain neurons from FXS individuals show defects in initial neurite outgrowth. Stem Cells Dev. 23, 1777-1787 (2014).

18. M. Telias, L. Kuznitsov-Yanovsky, M. Segal, D. Ben-Yosef, Functional deficiencies in fragile $X$ neurons derived from human embryonic stem cells. J. Neurosci. 35, 15295-15306 (2015).

19. Y. Li, X. Zhao, Concise review: Fragile $X$ proteins in stem cell maintenance and differentiation. Stem Cells 32, 1724-1733 (2014).

20. M. J. Boland, K. L. Nazor, H. T. Tran, A. Szücs, C. L. Lynch, R. Paredes, F. Tassone, P. P. Sanna, R. J. Hagerman, J. F. Loring, Molecular analyses of neurogenic defects in a human pluripotent stem cell model of fragile X syndrome. Brain 140, 582-598 (2017).

21. T. Halevy, C. Czech, N. Benvenisty, Molecular mechanisms regulating the defects in fragile $\mathrm{X}$ syndrome neurons derived from human pluripotent stem cells. Stem Cell Rep. 4, 37-46 (2015).

22. P. Lu, X. Chen, Y. Feng, Q. Zeng, C. Jiang, X. Zhu, G. Fan, Z. Xue, Integrated transcriptome analysis of human iPS cells derived from a fragile $X$ syndrome patient during neuronal differentiation. Sci. China Life Sci. 59, 1093-1105 (2016).

23. V. S. Achuta, H. Grym, N. Putkonen, V. Louhivuori, V. Kärkkäinen, J. Koistinaho, L. Roybon, M. L. Castrén, Metabotropic glutamate receptor 5 responses dictate differentiation of neural progenitors to NMDA-responsive cells in fragile X syndrome. Dev. Neurobiol. 77, 438-453 (2017).

24. W. Guo, A. M. Allan, R. Zong, L. Zhang, E. B. Johnson, E. G. Schaller, A. C. Murthy, S. L. Goggin, A. J. Eisch, B. A. Oostra, D. L. Nelson, P. Jin, X. Zhao, Ablation of Fmrp in adult neural stem cells disrupts hippocampus-dependent learning. Nat. Med. 17, 559-565 (2011).

25. M. Nakamoto, V. Nalavadi, M. P. Epstein, U. Narayanan, G. J. Bassell, S. T. Warren, Fragile $\mathrm{X}$ mental retardation protein deficiency leads to excessive mGluR5-dependent internalization of AMPA receptors. Proc. Natl. Acad. Sci. U.S.A. 104, 15537-15542 (2007).

26. H. Wang, S. S. Kim, M. Zhuo, Roles of fragile $X$ mental retardation protein in dopaminergic stimulation-induced synapse-associated protein synthesis and subsequent $\alpha$-amino-3-hydroxyl-5-methyl-4-isoxazole-4-propionate (AMPA) receptor internalization. J. Biol. Chem. 285, 21888-21901 (2010).
27. G. Uzunova, E. Hollander, J. Shepherd, The role of ionotropic glutamate receptors in childhood neurodevelopmental disorders: Autism spectrum disorders and fragile $X$ syndrome. Curr. Neuropharmacol. 12, 71-98 (2014).

28. G.-R. Cheng, X.-Y. Li, Y.-D. Xiang, D. Liu, S. M. McClintock, Y.Zeng, The implication of AMPA receptor in synaptic plasticity impairment and intellectual disability in fragile $X$ syndrome. Physiol. Res. 66, 715-727 (2017).

29. R. M. Meredith, R. de Jong, H. D. Mansvelder, Functional rescue of excitatory synaptic transmission in the developing hippocampus in Fmr1-KO mouse. Neurobiol. Dis. 41, 104-110 (2011).

30. L. C. Jansson, L. Louhivuori, H.-K. Wigren, T. Nordström, V. Louhivuori, M. L. Castrén, K. E. Åkerman, Effect of glutamate receptor antagonists on migrating neural progenitor cells. Eur. J. Neurosci. 37, 1369-1382 (2013).

31. L. C. Jansson, H.-K. Wigren, T. Nordström, K. E. Åkerman, Functional $\alpha$-amino-3-hydroxy-5methylisoxazole-4-propionic acid receptors in differentiating embryonic neural progenitor cells. Neuroreport 22, 282-287 (2011).

32. C. Y. Brazel, J. L. Nuñez, Z. Yang, S. W. Levison, Glutamate enhances survival and proliferation of neural progenitors derived from the subventricular zone. Neuroscience 131, 55-65 (2005).

33. M. Hollmann, S. Heinemann, Cloned glutamate receptors. Ann. Rev. Neurosci. 17, 31-108 (1994).

34. M. C. Angulo, B. Lambolez, E. Audinat, S. Hestrin, J. Rossier, Subunit composition, kinetic, and permeation properties of AMPA receptors in single neocortical nonpyramidal cells. J. Neurosci. 17, 6685-6696 (1997).

35. D. Bowie, M. L. Mayer, Inward rectification of both AMPA and kainate subtype glutamate receptors generated by polyamine-mediated ion channel block. Neuron 15, 453-462 (1995).

36. S. D. Donevan, M. A. Rogawski, Intracellular polyamines mediate inward rectification of $\mathrm{Ca}^{2+}$-permeable $\alpha$-amino-3-hydroxy-5-methyl-4-isoxazolepropionic acid receptors. Proc. Natl. Acad. Sci. U.S.A. 92, 9298-9302 (1995).

37. M. Eybalin, A. Caicedo, N. Renard, J. Ruel, J.-L. Puel, Transient $\mathrm{Ca}^{2+}$-permeable AMPA receptors in postnatal rat primary auditory neurons. Eur. J. Neurosci. 20, 2981-2989 (2004).

38. V. Lilliu, R. Pernas-Alonso, R. D. Trelles, U. di Porzio, A. Zuddas, C. Perrone-Capano, Ontogeny of AMPA receptor gene expression in the developing rat midbrain and striatum. Mol. Brain Res. 96, 133-141 (2001).

39. D. M. Talos, R. E. Fishman, H. Park, R. D. Folkerth, P. L. Follett, J. J. Volpe, F. E. Jensen, Developmental regulation of $\alpha$-amino-3-hydroxy-5-methyl-4-isoxazole-propionic acid receptor subunit expression in forebrain and relationship to regional susceptibility to hypoxic/ischemic injury. I. Rodent cerebral white matter and cortex. J. Comp. Neurol. 497, 42-60 (2006).

40. D. M. Talos, P. L. Follett, R. D. Folkerth, R. E. Fishman, F. L. Trachtenberg, J. J. Volpe, F. E. Jensen, Developmental regulation of $\alpha$-amino-3-hydroxy-5-methyl-4-isoxazolepropionic acid receptor subunit expression in forebrain and relationship to regional susceptibility to hypoxic/ischemic injury. II. Human cerebral white matter and cortex. J. Comp. Neurol. 497, 61-77 (2006).

41. S. S. Kumar, A. Bacci, V. Kharazia, J. R. Huguenard, A developmental switch of AMPA receptor subunits in neocortical pyramidal neurons. J. Neurosci. 22, 3005-3015 (2002).

42. E. Szczurowska, P. Ergang, H. Kubová, R. Druga, M. Salaj, P. Mareša, Influence of early life status epilepticus on the developmental expression profile of the GluA2 subunit of AMPA receptors. Exp. Neurol. 283, 97-109 (2016).

43. M. Zonouzi, M. Renzi, M. Farrant, S. G. Cull-Candy, Bidirectional plasticity of calcium-permeable AMPA receptors in oligodendrocyte lineage cells. Nat. Neurosci. 14, 1430-1438 (2011).

44. T. Lalanne, J. Oyrer, A. Mancino, E. Gregor, A. Chung, L. Huynh, S. Burwell, J. Maheux, M. Farrant, P. J. Sjöström, Synapse-specific expression of calcium-permeable AMPA receptors in neocortical layer 5. J. Physiol. 594, 837-861 (2016).

45. D. E. Pellegrini-Giampietro, R. S. Zukin, M. V. Bennett, S. Cho, W. A. Pulsinelli, Switch in glutamate receptor subunit gene expression in CA1 subfield of hippocampus following global ischemia in rats. Proc. Natl. Acad. Sci. U.S.A. 89, 10499-10503 (1992).

46. J. M. Spaethling, D. M. Klein, P. Singh, D. F. Meaney, Calcium-permeable AMPA receptors appear in cortical neurons after traumatic mechanical injury and contribute to neuronal fate. J. Neurotrauma 25, 1207-1216 (2008).

47. G. Whitehead, P. Regan, D. J. Whitcomb, K. Cho, $\mathrm{Ca}^{2+}$-permeable AMPA receptor: A new perspective on amyloid-beta mediated pathophysiology of Alzheimer's disease. Neuropharmacology 112, 221-227 (2017).

48. N. P. Whitney, H. Peng, N. B. Erdmann, C. Tian, D. T. Monaghan, J. C. Zheng, Calciumpermeable AMPA receptors containing Q/R-unedited GluR2 direct human neural progenitor cell differentiation to neurons. FASEB J. 22, 2888-2900 (2008).

49. V. Kärkkäinen, V. Louhivuori, M. L. Castrén, K. E. Åkerman, Neurotransmitter responsiveness during early maturation of neural progenitor cells. Differentiation 77, 188-198 (2009).

50. O. Khalfallah, M. Jarjat, L. Davidovic, N. Nottet, S. Cestèle, M. Mantegazza, B. Bardoni, Depletion of the fragile $X$ mental retardation protein in embryonic stem cells alters the kinetics of neurogenesis. Stem Cells 35, 374-385 (2017). 
51. N. I. Kiskin, O. A. Krishtal, A. Ya. Tsyndrenko, Excitatory amino acid receptors in hippocampal neurons: Kainate fails to desensitize them. Neurosci. Lett. 63, 225-230 (1986).

52. K. Tóth, C. J. McBain, Afferent-specific innervation of two distinct AMPA receptor subtypes on single hippocampal interneurons. Nat. Neurosci. 1, 572-578 (1998).

53. L.-D. Dong, F. Gao, X.-H. Wang, Y. Miao, S.-Y. Wang, Y. Wu, F. Li, J. Wu, X.-L. Cheng, X.-H. Sun, X.-L. Yang, Z. Wang, GluA2 trafficking is involved in apoptosis of retinal ganglion cells induced by activation of EphB/EphrinB reverse signaling in a rat chronic ocular hypertension model. J. Neurosci. 35, 5409-5421 (2015).

54. S. E. Scherer, V. Gallo, Expression and regulation of kainate and AMPA receptors in the rat neural tube. J. Neurosci. Res. 52, 356-368 (1998).

55. D. Maric, Q.-Y. Liu, G. M. Grant, J. D. Andreadis, Q. Hu, Y. H. Chang, J. L. Barker, J. Joseph, D. A. Stenger, W. Ma, Functional ionotropic glutamate receptors emerge during terminal cell division and early neuronal differentiation of rat neuroepithelial cells. J. Neurosci. Res. 61, 652-662 (2000)

56. M. Suzuki, A. D. Nelson, J. B. Eickstaedt, K. Wallace, L. S. Wright, C. N. Svendsen, Glutamate enhances proliferation and neurogenesis in human neural progenitor cell cultures derived from the fetal cortex. Eur. J. Neurosci. 24, 645-653 (2006).

57. O. P. Voss, S. Milne, J. Sharkey, M. J. O'Neill, J. McCulloch, Molecular mechanisms of neurite growth with AMPA receptor potentiation. Neuropharmacology 52, 590-597 (2007).

58. W. Guo, E. D. Polich, J. Su, Y. Gao, D. M. Christopher, A. M. Allan, M. Wang, F. Wang, G. Wang, X. Zhao, Fragile X proteins FMRP and FXR2P control synaptic GluA1 expression and neuronal maturation via distinct mechanisms. Cell Rep. 11, 1651-1666 (2015).

59. R. Saba, P. H. Störchel, A. Aksoy-Aksel, F. Kepura, G. Lippi, T. D. Plant, G. M. Schratt, Dopamine-regulated microRNA MiR-181a controls GluA2 surface expression in hippocampal neurons. Mol. Cell Biol. 32, 619-632 (2012).

60. M. M. Ghahramani Seno, P. Hu, F. G. Gwadry, D. Pinto, C. R. Marshall, G. Casallo, S. W. Scherer, Gene and miRNA expression profiles in autism spectrum disorders. Brain Res. 1380, 85-97 (2011).

61. N. J. Beveridge, P. A. Tooney, A. P. Carroll, E. Gardiner, N. Bowden, R. J. Scott, N. Tran, I. Dedova, M. J. Cairns, Dysregulation of miRNA $181 \mathrm{~b}$ in the temporal cortex in schizophrenia. Hum. Mol. Genet. 17, 1156-1168 (2008).

62. B. Stepniak, A. Kästner, G. Poggi, M. Mitjans, M. Begemann, A. Hartmann, S. Van der Auwera, F. Sananbenesi, D. Krueger-Burg, G. Matuszko, C. Brosi, G. Homuth, H. Völzke, F. Benseler, C. Bagni, U. Fischer, A. Dityatev, H.-J. Grabe, D. Rujescu, A. Fischer, $\mathrm{H}$. Ehrenreich, Accumulated common variants in the broader fragile $\mathrm{X}$ gene family modulate autistic phenotypes. EMBO Mol. Med. 7, 1565-1579 (2015).

63. K. Zhang, Q. Wang, X. Jing, Y. Zhao, H. Jiang, J. Du, S. Yu, M. Zhao, miR-181a is a negative regulator of GRIA2 in methamphetamine-use disorder. Sci. Rep. 6, 35691 (2016).

64. E. R. Hutchison, E. M. Kawamoto, D. D. Taub, A. Lal, K. Abdelmohsen, Y. Zhang, W. H. Wood III, E. Lehrmann, S. Camandola, K. G. Becker, M. Gorospe, M. P. Mattson, Evidence for miR-181 involvement in neuroinflammatory responses of astrocytes. Glia 61, 1018-1028 (2013).

65. Y. M. Choi, S. H. Kim, D. Y. Uhm, M. K. Park, Glutamate-mediated $\left[\mathrm{Ca}^{2+}\right]_{\mathrm{C}}$ dynamics in spontaneously firing dopamine neurons of the rat substantia nigra pars compacta. J. Cell Sci. 116, 2665-2675 (2003).

66. A. Bhattacharyya, E. McMillan, K. Wallace, T. C. Tubon Jr., E. E. Capowski, C. N. Svendsen, Normal neurogenesis but abnormal gene expression in human fragile $\mathrm{X}$ cortical progenitor cells. Stem Cells Dev. 17, 107-118 (2008).

67. G. La Fata, A. Gärtner, N. Domínguez-Iturza, T. Dresselaers, J. Dawitz, R. B. Poorthuis, M. Averna, U. Himmelreich, R. M. Meredith, T. Achsel, C. G. Dotti, C. Bagni, FMRP regulates multipolar to bipolar transition affecting neuronal migration and cortical circuitry. Nat. Neurosci. 17, 1693-1700 (2014).

68. M. Hollmann, M. Hartley, S. Heinemann, $\mathrm{Ca}^{2+}$ permeability of KA-AMPA-gated glutamate receptor channels depends on subunit composition. Science 252, 851-853 (1991).

69. S. J. Liu, R. S. Zukin, $\mathrm{Ca}^{2+}$-permeable AMPA receptors in synaptic plasticity and neuronal death. Trends Neurosci. 30, 126-134 (2007).

70. H. Hu, Y. Qin, G. Bochorishvili, Y. Zhu, L. van Aelst, J. J. Zhu, Ras signaling mechanisms underlying impaired GluR1-dependent plasticity associated with fragile $X$ syndrome. J. Neurosci. 28, 7847-7862 (2008).
71. S. M. Till, L. S. Wijetunge, V. G. Seidel, E. Harlow, A. K. Wright, C. Bagni, A. Contractor, T. H. Gillingwater, P. C. Kind, Altered maturation of the primary somatosensory cortex in a mouse model of fragile X syndrome. Hum. Mol. Genet. 21, 2143-2156 (2012).

72. C. J. Schoenherr, D. J. Anderson, Silencing is golden: Negative regulation in the control of neuronal gene transcription. Curr. Opin. Neurobiol. 5, 566-571 (1995).

73. A. Baskys, I. Bayazitov, L. Fang, M. Blaabjerg, F. R. Poulsen, J. Zimmer, Group I metabotropic glutamate receptors reduce excitotoxic injury and may facilitate neurogenesis. Neuropharmacology 49 (suppl. 1), 146-156 (2005).

74. G. Robin, J. R. López, G. M. Espinal, S. Hulsizer, P. J. Hagerman, I. N. Pessah, Calcium dysregulation and Cdk5-ATM pathway involved in a mouse model of fragile X-associated tremor/ataxia syndrome. Hum. Mol. Genet. 26, 2649-2666 (2017).

75. H. Wang, L. C. Doering, Autism spectrum disorders: Emerging mechanisms and mechanism-based treatment. Front. Cell. Neurosci. 9, 183 (2015).

76. M. Fromer, A. J. Pocklington, D. H. Kavanagh, H. J. Williams, S. Dwyer, P. Gormley, L. Georgieva, E. Rees, P. Palta, D. M. Ruderfer, N. Carrera, I. Humphreys, J. S. Johnson, P. Roussos, D. D. Barker, E. Banks, V. Milanova, S. G. Grant, E. Hannon, S. A. Rose, K. Chambert, M. Mahajan, E. M. Scolnick, J. L. Moran, G. Kirov, A. Palotie, S. A. McCarroll, P. Holmans, P. Sklar, M. J. Owen, S. M. Purcell, M. C. O'Donovan, De novo mutations in schizophrenia implicate synaptic networks. Nature 506, 179-184 (2014).

77. M. Mikkola, S. Toivonen, K. Tamminen, K. Alfthan, T. Tuuri, T. Satomaa, J. Natunen J. Saarinen, M. Tiittanen, M. Lampinen, L. Valmu, J. Partanen, T. Otonkoski, Lectin from Erythrina cristagalli supports undifferentiated growth and differentiation of human pluripotent stem cells. Stem Cells Dev. 22, 707-716 (2012).

78. R. Nat, M. Nilbratt, S. Narkilahti, B. Winblad, O. Hovatta, A. Nordberg, Neurogenic neuroepithelial and radial glial cells generated from six human embryonic stem cell lines in serum-free suspension and adherent cultures. Glia 55, 385-399 (2007).

79. V. S. Achuta, V. Rezov, M. Uutela, V. Louhivuori, L. Louhivuori, M. L. Castrén, Tissue plasminogen activator contributes to alterations of neuronal migration and activity-dependent responses in fragile X mice. J. Neurosci. 34, 1916-1923 (2014).

80. R. A. McCloy, S. Rogers, C. E. Caldon, T. Lorca, A. Castro, A. Burgess, Partial inhibition of Cdk1 in $\mathrm{G}_{2}$ phase overrides the SAC and decouples mitotic events. Cell Cycle 13, 1400-1412 (2014).

81. K. J. Livak, T. D. Schmittgen, Analysis of relative gene expression data using real-time quantitative PCR and the $2^{-\Delta \Delta C}$ method. Methods 25, 402-408 (2001).

Acknowledgments: We thank the Finnish Fragile X Family Association (Frax ry) and all the families that participated in the study. The iPSC lines were generated in the Biomedicum Stem Cell Center, University of Helsinki. The transcriptome profiling was performed at the Biomedicum Functional Genomics Unit, University of Helsinki. We thank O. Nikkilä for mouse genotyping, L. Louhivuori for helping with intracellular calcium recordings, and C. Kanduri for approving the statistical methods used. We are very grateful to M. Kaski for actively supporting research in the Rinnekoti Foundation. Funding: This work was supported by grants from the Finnish Brain Research Foundation, Arvo and Lea Ylppö Foundation, Sakari and Orvokki Sohlberg Foundation, Foundation for Pediatric Research, Finnish Medical Foundation, Magnus Ehrnrooth Foundation, and Academy of Finland. Author contributions: V.S.A., T.M., U.-K.P., and G.T. performed the research and analyzed the data together with C.R., K.K., and M.L.C. V.S.A. and M.L.C. wrote the manuscript with critical comments from C.R. and K.K. Competing interests: The authors declare that they have no competing interests. Data and materials availability: The human microarray data reported in this paper are available at the Gene Expression Omnibus database under accession no. GSE103965.

Submitted 2 June 2017

Accepted 19 December 2017

Published 16 January 2018

10.1126/scisignal.aan8784

Citation: V. S. Achuta, T. Möykkynen, U.-K. Peteri, G. Turconi, C. Rivera, K. Keinänen, M. L. Castrén Functional changes of AMPA responses in human induced pluripotent stem cell-derived neural progenitors in fragile X syndrome. Sci. Signal. 11, eaan8784 (2018). 


\section{ScienceSignaling}

\section{Functional changes of AMPA responses in human induced pluripotent stem cell-derived neural progenitors in fragile $X$ syndrome}

Venkat Swaroop Achuta, Tommi Möykkynen, Ulla-Kaisa Peteri, Giorgio Turconi, Claudio Rivera, Kari Keinänen and Maija L. Castrén

Sci. Signal. 11 (513), eaan8784.

DOI: $10.1126 /$ scisignal.aan8784

\section{Calcium-permeable AMPARs in FXS}

The intellectual disability disorder FXS (fragile X syndrome) is associated with changes in neuronal function and circuitry in the brain that impair synaptic plasticity, which is critical to learning. Among these changes are increased excitability, impaired maturation of neural structures, and altered differentiation of neural stem cells. To explore these phenotypes in human neurons, Achuta et al. engineered neuronal progenitors from human primary fibroblasts. In those derived from boys with FXS, the expression of the AMPA receptor subunit GluA2 was decreased, which resulted in a greater number of AMPA receptors that lacked GluA2 and thus facilitated increased calcium influx into the cells. Pharmacologically blocking GluA2-lacking AMPA receptors in FXS-derived cultures and in FXS mouse models restored normal neuronal function and phenotypes. The decrease in GluA2 may be mediated by the abnormal abundance or mislocalization of a repressive microRNA due to loss of the RNA binding protein FMRP, which causes FXS.

ARTICLE TOOLS

SUPPLEMENTARY MATERIALS

RELATED

REFERENCES

PERMISSIONS http://stke.sciencemag.org/content/11/513/eaan8784

http://stke.sciencemag.org/content/suppl/2018/01/11/11.513.eaan8784.DC1

http://stke.sciencemag.org/content/sigtrans/10/477/eaai8133.full http://stke.sciencemag.org/content/sigtrans/10/504/eaan0852.full $\mathrm{http} / / /$ stke.sciencemag.org/content/sigtrans/10/504/eaan0665.full http://stke.sciencemag.org/content/sigtrans/10/504/eaan3181.full http://science.sciencemag.org/content/sci/351/6275/863.full http://stm.sciencemag.org/content/scitransmed/8/321/321ra5.full

This article cites 81 articles, 17 of which you can access for free http://stke.sciencemag.org/content/11/513/eaan8784\#BIBL

http://www.sciencemag.org/help/reprints-and-permissions registered trademark of AAAS. 